\title{
Affective trajectories: locating diegetic velocity in the cinema experience
}

Article

Accepted Version

Purse, L. (2016) Affective trajectories: locating diegetic velocity in the cinema experience. Cinema Journal, 55 (2). pp. 151-157. ISSN 0009-7101 (IN FOCUS: Speed) Available at http://centaur.reading.ac.uk/55370/

It is advisable to refer to the publisher's version if you intend to cite from the work. See Guidance on citing.

Published version at: http://www.cmstudies.org/?page=CJ_in_focus

Publisher: University of Texas Press

Publisher statement: This is a pre-copyedited version of an article accepted for publication in (journal title) following peer review. The definitive publisherauthenticated version is available through the University of Texas Press.

All outputs in CentAUR are protected by Intellectual Property Rights law, including copyright law. Copyright and IPR is retained by the creators or other copyright holders. Terms and conditions for use of this material are defined in the End User Agreement. 


\section{www.reading.ac.uk/centaur}

\section{CentAUR}

Central Archive at the University of Reading

Reading's research outputs online 
Affective Trajectories: Locating Diegetic Velocity in the Cinema Experience Lisa Purse

Cinema's own speeds seem to be increasingly at issue. The contemplative "cinema of slowness" of directors such as Béla Tarr, Tsai Ming-liang, and Nuri Bilge Ceylan is valorized at the expense of a "fast" cinema-action-filled blockbusters like the Bourne films (The Bourne Identity (Doug Liman, 2002), The Bourne Supremacy (Paul Greengrass, 2004), The Bourne Ultimatum (Paul Greengrass, 2007), The Bourne Legacy (Tony Gilroy, 2012)) and the Transformers franchise (Transformers (Michael Bay, 2007), Transformers: Revenge of the Fallen (Michael Bay, 2009), Transformers: Dark of the Moon (Michael Bay, 2011), Transformers: Age of Extinction (Michael Bay, 2014)) — that is persistently dismissed for its formal and narrative preoccupation with acceleration. ${ }^{1}$ The negative positioning of popular films that make the heightened diegetic velocity of bodies, vehicles, and objects their subject is not in itself new, but what is notable is its combination with a growing critical focus on these films' presentational speeds. ${ }^{2}$ From David Bordwell's writing on intensified continuity to Steven Shaviro's work on post-continuity, critics and film scholars have highlighted the quickening pace of editing and camera movement in mainstream American cinema, foregrounding the pressure this puts on continuity editing's traditional role of marking out spatio-temporal relations in explicitly visual terms. ${ }^{3}$ In the ensuing critical discussion it has become commonplace to suggest that, as "fast" cinema has speeded up, so the spectator has lost more of her sense of diegetic spatial relationships. I want to suggest that this critical commonplace obscures important 
aspects of both the relationship between speed and visual narration, and the experience of intense diegetic velocities.

In 2011, Matthias Stork published three video essays on what he called "Chaos Cinema," illustrated with high-speed action sequences from films like Transformers (Michael Bay, 2007), Bad Boys II (Michael Bay, 2003), Quantum of Solace (Marc Foster, 2008), and the Bourne franchise. This cinema, he suggested, deploys rapid editing and shaky camera movements to "overwhelm" and "overpower" audiences, and in doing so obscures "trades visual intelligibility for sensory overload. ${ }^{, 4}$ In the same year, Jim Emerson deployed video essays to undertake a pointed comparison between high-speed chase sequences in Salt (Phillip Noyce, 2010), The Dark Knight (Christopher Nolan, 2008), and older films like Bullitt (Peter Yates, 1968) and The French Connection (William Friedkin, 1971), in which The Dark Knight's inconsistent deployment of screen direction is held up as an example of those films that deploy fast, mobile framing, and high-speed dissection of space without sustaining "spatial integrity between elements within the frame or between shots," thus producing "sensation without orientation." Emerson and Stork are echoing David Bordwell's long-established preference for "sensation" to be anchored by clarity of physical action, and by a spatial legibility located in the image track and the cut. ${ }^{6}$ Yet such a preference carries echoes of what Adrian Martin has called "the baggage of classicism": an overvaluing of coherence, narrative articulation, and formal balance that risks preventing adequate attention to those moments, sequences, or films constructed along other kinds of aesthetic principles. ${ }^{7}$

The fact that so many writers are demanding this type of visually-conveyed spatial clarity from the intense diegetic velocities and presentational speeds of popular cinema is symptomatic, it seems to me, of cultural anxieties about how we orient 
ourselves in relation to intensifying technological, social, geographical and economic accelerations that have constructed a "speeded-up world in which . . . everyday life skids along on the plane of velocity" — and about, in particular, the "negation of space" these accelerations imply. ${ }^{8}$ Paul Virilio has influentially argued that the accelerating speeds of contemporary technologization and modern transportation are changing our relationships to geography, terrain, and territory, producing an increasingly "fleeting figuration of the transfer" between different locations, or what he elsewhere calls the "ruin of the interval." In the era of drone warfare, the circumstance of being unable to visually verify one's spatial orientation in relation to fast-moving screen action might well reverberate with a more general unease about one's orientation to the state and military capacities for near-instantaneous spatial penetration that Virilio so astutely described. ${ }^{10}$ In this cultural context, a clearly visually mapped and spatially coherent mode of presenting the speeds of screen action may have a reassuring function, even a nostalgic one.

This is not a reason to preserve optical-spatial intelligibility as a dominant principle in the cinematic representation of intense diegetic velocities, however. Deborah Levitt reminds us that the "spatiality of physiological vision is not . . . easily diagrammed," so that "the determination of the 'truth' of a particular vision cannot take place on the basis of a clear spatial mapping."11 Human beings make sense of the world through dynamic, holistic and continual processes of synthesis and interpretation of different visual and proprioceptive stimuli over time, including information glimpsed or snatched on the fly; partial inputs that do not clarify orientation or environment in themselves but instead do so cumulatively. Why should not a cinema of speed reflect and speak to this contingency inherent in processes of visual cognition? Moreover, there are other ways in which cinema is able to orient the 
spectator in relation to the experience of diegetic speed. To illustrate this, let's look at the final car chase of The Bourne Supremacy (Paul Greengrass, 2004), which sits within a film franchise that garnered controversy for its allegedly "spasmodic" editing and obfuscatory "shaky cam" mode of visual narration. ${ }^{12}$

The chase through Moscow's streets lasts around six minutes, from Jason Bourne (Matt Damon)'s commandeering of a taxi, through his attempts to evade a closing dragnet of police vehicles and an assassin, Kirill (Karl Urban), also in hot pursuit, to the crash in an underground tunnel that stops Kirill in his tracks. One section in particular would make Bordwell proud. Bourne's taxi powers past the camera in a blur, leaving two police cars in the frame, gunning their engines to make up ground, their sirens getting louder as they get closer. The shared orientation and movement of the three vehicles mark out a spatially legible linear trajectory along the $\mathrm{x}$-axis, with consistency of screen direction reinforced through eye-line matches as two sets of police drivers look towards their quarry and Bourne returns their gaze. A cut to the taxi interior picks up the accelerating police cars in the rear windscreen, before a whip-pan right frames Bourne anxiously looking in the rear view mirror to check just how close those police cars are. It is at this moment, when both Bourne's and the spectator's attention is on the pair of police cars gaining ground from behind, that a third police car slams into Bourne's taxi sideways, unheralded except for the briefest screeching of brakes.

[Place Figures 1 through 4, ideally in a group, about here]

Figure 1. An interior shot of the foot-well as Bourne hits the throttle in The Bourne Supremacy 
Figure 2. Cut to an exterior shot of Bourne's taxi moving screen left to screen right Figure 3. Cut to an interior shot, the taxi's screen direction now right to left Figure 4. Cut to an interior shot from the pursuing police car, as Bourne speeds away

The side impact of the third police car is surprising not only because the edit withholds its approach, but because its trajectory interrupts, strikingly and suddenly, the trajectory within which the spectator has been affectively invested. Bordwell would argue that the experiential force of this interruption is founded on the spatial legibility of the preceding few shots I've described, which tie the chase's trajectory to the literal linearity of the street the cars are travelling down. Yet if this is so, why not make the whole chase spatially legible in this way? Instead, most of the chase scene consists of a shifting array of contradictory screen directions (Figures 1-4) alternated with blurry shots of car interiors (a close-up of Bourne's face; a gear stick; the pedals). Only occasionally is this maelstrom of camera angles, movements and cuts punctuated with brief revelations of spatial relations between vehicles at narratively significant moments, either through groupings of shots that momentarily sustain screen direction (for example, the parallel montage with appropriate alternations of screen direction and looks off-screen when Bourne and Kirill spot each other travelling parallel on either side of the river), an in-shot reframing or whip-pan (say, to reveal a Russian Federal Security Service vehicle or police car in pursuit), or the entry of a vehicle into the frame (as when a shot of Bourne's taxi skidding left behind a moving tram is developed by Kirill entering frame right to converge on Bourne's position: see figure 5). Why persist in this spatial illegibility, this strategy of constantly switching visual-spatial orientations in relation to the unfolding speeds of action? 
[Place Figure 5 about here]

Figure 5. Bourne's taxi and Kirill's black truck converge in the same frame

Put simply, the film spectator can be imaginatively oriented towards particular diegetic trajectories without having to continuously see them (or see them continuously literalized): it is sufficient to understand the situation in which those trajectories develop or are asserted. As Sara Ahmed, following Maurice MerleauPonty, explains, embodied orientation is about more than measuring where we might literally be spatially situated. Orientations, she observes, "involve different ways of registering the proximity of objects and others. Orientations shape not only how we inhabit space, but how we apprehend this world of shared inhabitance."13 The spectator's understanding of the characters' situatedness necessarily includes an awareness of generic and narrative coordinates that produce orientations beyond the literal. The generic terrain that the Bourne films occupy provides fantasies of bodily movement directed along what Erin Manning has called "vectors of emergence" that are characterized by propulsion and spatial penetration, exertion and risk. ${ }^{14}$ The chase sequence locks pursuer and pursued into an intensely affective linear trajectory of fear, anticipation, shared exertion, and determined directedness, magnified by a narrative framing that aligns the spectator with a particular character's asserted position along that trajectory. Throughout the chase in question, Bourne's desire to escape invites imaginative investment in a particular vectorial aspiration — away from here, now, fastest - that remains in place regardless of whether the spatial relations of the scene are visually verifiable or not. 
In his poetics of film-thinking, Daniel Frampton cautions that it is "limiting to talk about film form in terms of our perceptual capabilities - film can do more than us, differently to us." ${ }^{15}$ Popular cinema is free to "think" bodies-at-speed in ways other than the literal show-and-tell, and is increasingly doing so. In this "fast" cinema, spatial legibility's role begins to come into focus, the exception that proves the (new) rule, a tool for momentary emphasis, if it is needed at all. And yet this is not the "sensation without orientation" that Emerson alleged, for fast cinema's affective trajectories remain as narratively situated as their spatially legible ancestors. 
${ }^{1}$ Michel Ciment coined the term in his "The State of Cinema" address, 46th San Francisco International Film Festival (2003), http://web.archive.org/web/20040325130014/http://www.sfiff.org/fest03/special/state. html. See also Matthew Flanagan, "16:9 in English: Toward an Aesthetic of Slow in Contemporary Cinema," 16:9 29 (2008): http://www.16-9.dk/2008-

11/side11_inenglish.htm. Such slow cinema is often seen as a direct reaction against the accelerations of mainstream American Cinema, although as Tiago de Luca suggests, this both legitimizes Hollywood as a dominant paradigm and elides both the varied factors that have prompted the many directors grouped together under this rubric to adopt this mode of filmmaking, and the aesthetic differences between them. Tiago De Luca, Realism of the Senses in World Cinema: The Experience of Physical Reality (Basingstoke: Palgrave Macmillan, 2014), 13-18; see also Steven Shaviro, “Slow Cinema vs. Fast Films," The Pinocchio Theory, May 12, 2010, http://www.shaviro.com/Blog/?p=891.

${ }^{2}$ As Yvonne Tasker points out, this sector of film production has "consistently failed to meet the markers of aesthetic and cultural value typically applied within contemporary film culture." In "Introduction," Action and Adventure Cinema (Abingdon: Routledge, 2004), 2.

${ }^{3}$ David Bordwell, The Way Hollywood Tells It: Story and Style in Modern Movies (Berkeley and Los Angeles: University of California Press, 2006); Steven Shaviro, Post-Cinematic Affect (Winchester: Zero Books, 2010). As Thomas Elsaesser and Malte Hagener note, continuity editing comprises the set of editing rules that "allow for an inconspicuous compression of space and time at the same time as it creates and maintains a spatial and temporal coherence," including cuts on movement or action, 
eye line match, and maintaining screen direction across shots. In Film Theory: An Introduction Through the Senses (London: Routledge, 2010), 90.

${ }^{4}$ Matthias Stork, "Video Essay: Chaos Cinema: The Decline and Fall of Action Filmmaking," PressPlay IndieWire, August 22, 2011, http://blogs.indiewire.com/pressplay/video_essay_matthias_stork_calls_out_the _chaos_cinema; see also Stork, "Video Essay: Chaos Cinema, Part 3; Matthias Stork Addresses his Critics," PressPlay IndieWire, December 9, 2011, http://blogs.indiewire.com/pressplay/matthias-stork-chaos-cinema-part-3. 5 Jim Emerson, "In The Cut, Part I: Shots in the Dark (Knight)," Scanners, September 8, 2011, http://www.rogerebert.com/scanners/in-the-cut-part-i-shots-in-thedark-knight; see also Emerson, "In The Cut, Part II: A Dash of Salt,” Scanners, September 13, 2011, http://www.rogerebert.com/scanners/in-the-cut-part-ii-adash-of-salt, and Emerson, "In The Cut, Part III: Bullitt, The Lineup, French Connection aka I Left My Heart in My Throat in San Francisco," Scanners, September 16, 2011, http://www.rogerebert.com/scanners/in-the-cut-part-iiibullitt-the-lineup-french-connectionaka-i-left-my-heart-in-my-throat-in-sanfrancisco.

6 "In a film of physical action," Bordwell proposes, "the audience needs to be firmly oriented to the space and the people present. In "[Insert your Favorite Bourne Pun Here]," Observations on Film Art, August 30, 2007, http://www.davidbordwell.net/blog/2007/08/30/insert-your-favorite-bournepun-here/. See also Bordwell, "Unsteadicam Chronicles," Observations on Film Art, August 17, 2007, http://www.davidbordwell.net/blog/2007/08/17/unsteadicam-chronicles/. 
${ }^{7}$ Adrian Martin, "Turn the Page: From Mise en Scène to Dispositif," Screening the Past July, 2011, paragraph 45, http://www.screeningthepast.com/2011/07/turnthe-page-from-mise-en-scene-to-dispositif/.

${ }^{8}$ Critics of modernity's logic of acceleration include Paul Virilio in works like Speed and Politics: An Essay on Dromology, trans. Mark Polizzotti (Los Angeles:

Semiotext(e), 2006), and Negative Horizon: An Essay on Dromoscopy, trans. Michael Degener (London: Continuum, 2008); Jean Baudrillard in works like The Illusion of the End, trans. Chris Turner (Cambridge: Polity Press, 1995), and Hartmut Rosa, Social Acceleration: A New Theory of Modernity, trans. Jonathan Trejo-Mathys (New York: Columbia University Press, 2013). It is Virilio who worries that acceleration produces a "negation of space", in Speed and Politics, 149. Nigel Thrift's invocation of fears around this "speeded-up world", in Non-Representational Theory: Space, Politics, Affect (London: Routledge, 2007), 63, is part of a wider discussion that usefully interrogates the underpinning technological determinism of such accounts which, Thrift suggests, "unproblematically maps the apparent powers of things on to subjects", and points out that speed is "in part a cultural creation, a classical modernist trope now in general cultural circulation" (ibid., 63).

${ }^{9}$ Virilio, Negative Horizon: An Essay in Dromoscopy, 105.

${ }^{10}$ See in particular Virillio's "The State of Emergency" chapter in Speed and Politics, $149-67$.

${ }^{11}$ Deborah Levitt, "Image as Gesture: The Saint in Chrome Dioxide," Spectator 21, no. 2 (2002): 23-39, 30 .

12 "spasmodic" editing is Bordwell's term, used in his blog post, "Unsteadicam Chronicles,” paragraph 6. See also Bordwell, “[Insert your Favorite Bourne Pun Here]," Roger Ebert, “Shake, Rattle, and Bourne!," Roger Ebert's Journal, August 
16, 2007, http://www.rogerebert.com/rogers-journal/shake-rattle-and-bourne, and Jim Emerson, "Fasten your Seatbelts, it’s Gonna be a Bumpy Bourne!," Scanners, August 17, 2007, http://www.rogerebert.com/scanners/fasten-yourseatbelts-its-gonna-be-a-bumpy-bourne.

${ }^{13}$ Sara Ahmed, Queer Phenomenology: Orientations, Objects, Others (London: Duke University Press, 2006), 2, emphases added. Merleau-Ponty suggested that, in lived experience, the body's directedness towards existing or possible tasks is experienced not as "a spatiality of position, but a spatiality of situation." In Phénomènology de la perception (Phenomenology of Perception) (Paris: Gallimard, 1945), translated by Colin Smith for the English edition (London: Routledge \& Kegan Paul, 1962), excerpted in Thomas Baldwin (ed.), Maurice Merleau-Ponty: Basic Writings (London: Routledge, 2004), 104, original emphasis.

${ }^{14}$ Drawing on Gilles Deleuze and Félix Guattari’s "Body without Organs" concept, elaborated in L'anti-Oedipe (Anti-Oedipus) (Paris: Les Éditions de Minuit, 1972) and Mille plateaux (A Thousand Plateaus) (Paris: Les Éditions de Minuit, 1980), Erin Manning describes bodies as "vectors of emergence that generate virtual embodiments in a future anterior that we can only reach towards." In Politics of Touch: Sense, Movement, Sovereignty (London: University of Minneapolis Press, 2007), 120.

${ }^{15}$ Daniel Frampton, Filmosophy (Chichester: Wallflower Press, 2006), 46. 